\title{
Risky sexual behaviours among injection drugs users with high HIV prevalence: implications for STD control
}

\author{
M W Tyndall, D Patrick, P Spittal, K Li, M V O'Shaughnessy, M T Schechter
}

Sex Transm Infect 2002;78(Suppl I):i170-i 175

Injection drug use is inextricably linked to commercial sex work and the transmission of sexually transmitted disease (STD). In many communities prevention efforts have been stalled owing to the marginal existence of this community. This study describes the sexual activities, condom use, reported STDs, and commercial sex work in a large cohort of injection drug users. Seventy two per cent of male and $92 \%$ of female subjects in the cohort were sexually active. Among female subjects, $57 \%$ reported more than 100 lifetime partners.

Condoms were generally not used with regular partners, used about half the time with casual partners, and used about $80 \%$ of the time with paying partners. Female sex workers were more likely to have unstable housing and to report incarceration in the previous six months. Reducing the transmission of STDs and HIV in drug using communities is a public health priority. While existing prevention programmes should be strengthened, innovative approaches to STD surveillance, diagnosis, and prevention are needed.

See end of article for authors' affiliations

Correspondence to: Dr Mark W Tyndall, British Columbia Centre for Excellence in HIV/AIDS, St Paul's Hospital, 1081

Burrard St, Vancouver, BC, Canada V6Z 1Y6. tyndallm@hivnet.ubc.ca

Accepted

6 December 2001
S exually transmitted diseases (STDs) are endemic in communities with illicit drug use, perpetuated by the inextricable link between drug use and commercial sex work. ${ }^{1-5}$ In most drug using populations it is young women who are at the greatest risk of contracting STDs, including HIV. ${ }^{6-8}$ In particular, the use of injection cocaine and crack cocaine, widely available in Vancouver, has been closely associated with risky sexual practices and high rates of STD transmission. ${ }^{10}$ Prevention efforts targeted at injection drug users have focused primarily on the reduction of HIV through the provision of clean syringes. Sexual transmission of HIV and other STDs has not been a high priority. ${ }^{11}$ The establishment of social and sexual networks among drug users has important implications for risk behaviours and interventions. ${ }^{13} 14$

The rapid and alarming spread of HIV and hepatitis C in Vancouver's downtown eastside (DTES) during the 1990s has drawn international attention to this troubled community. ${ }^{15}{ }^{16}$ It is estimated that 4700 injection drug users reside in an area of 10 city blocks. Despite intensive community efforts, escalating government spending, expansion of primary health care, and numerous harm reducing initiatives, high rates of injection drug use and dismal health outcomes persist. Frequently cited in national news media as Canada's poorest neighbourhood, Vancouver's DTES is plagued by unemployment, crime, mental illness, prostitution, and inadequate housing. HIV seroconversion rates and overdose deaths outstrip those of other North American cities, with statistics showing that from 1991-98 almost 25\% of British Columbia's drug induced deaths occurred in the DTES. ${ }^{17}$ Although often described in isolation, the DTES is centrally located and borders on the city's financial district, an international seaport, and a popular tourist area. This has contributed to endemic rates of STD within the affected population and an ongoing focus of STD transmission for people from outside the community.

We assessed the sexual behaviours reported by a large cohort of injection drug users in this neighbourhood, with a focus on sexual relationships, sexual behaviours, STD rates, and reported condom use. This analysis illustrates the complex and dynamic nature of STD transmission in a drug using community and the importance of social network formation. It can be shown that phase appropriate strategies for prevention are critical within drug using communities and that evaluation of interventions should be a priority.

\section{METHODS}

\section{Study population}

The Vancouver injection drug users study (VIDUS) is a prospective study of over 1400 injection drug users that began in May 1996 during an explosive outbreak of HIV in Vancouver's DTES. The study established a storefront office, with participants coming to the study through local advertisements and word of mouth. For study enrolment participants had to give a history of injection drug use in the proceeding month and provide written informed consent. Blood samples for HIV and hepatitis C antibody testing are collected, and each participant undergoes an interview administered questionnaire at the baseline visit and semi-annually thereafter. Participants are reimbursed Cdn $\$ 20$ for each study visit, at which time referrals are provided for medical care, HIV/AIDS care, drug and alcohol treatment, and counselling. Detailed information is collected on demographics, sexual behaviours, types of drugs injected, frequency of drug use, incarceration, housing, and the utilisation of health services such as emergency departments, clinics, and hospitals.

\section{Statistical analysis}

Univariate statistical techniques were applied to determine factors associated with female sex work. Categorical explanatory variables were 


\begin{tabular}{|c|c|c|}
\hline Characteristic & $\begin{array}{l}\text { Male } \\
(n=932)\end{array}$ & $\begin{array}{l}\text { Female } \\
(n=505)\end{array}$ \\
\hline Age (mean (range)) (years) & $\begin{array}{l}35.3 \\
(16 \text { to } 58)\end{array}$ & $\begin{array}{l}31.4 \\
(14 \text { to } 58)\end{array}$ \\
\hline Time injecting (mean (range)) (years) & $\begin{array}{l}14.3 \\
(0.1 \text { to } 44)\end{array}$ & $\begin{array}{l}11.8 \\
(0.1 \text { to } 40)\end{array}$ \\
\hline \multicolumn{3}{|l|}{ Ethnicity } \\
\hline White & $582(62)$ & $283(56)$ \\
\hline Aboriginal & $168(18)$ & $194(38)$ \\
\hline Hispanic & $78(8)$ & $4(1)$ \\
\hline Asian & $58(6)$ & $9(2)$ \\
\hline Other & $46(5)$ & $15(3)$ \\
\hline Welfare/disability recipient & 659 (71) & 347 (69) \\
\hline Education (at least elementary) & $708(76)$ & $406(80)$ \\
\hline \multicolumn{3}{|l|}{ Housing } \\
\hline Hotel (single room occupancy) & $432(46)$ & $212(42)$ \\
\hline Apartment & $292(31)$ & $172(34)$ \\
\hline Boarding house/hostel & $67(7)$ & $32(6)$ \\
\hline Other* & $141(16)$ & $89(18)$ \\
\hline Jail (ever) & 736 (79) & $355(70)$ \\
\hline HIV positive & $241(26)$ & 178 (35) \\
\hline Hepatitis $C$ positive & $797(86)$ & $439(87)$ \\
\hline \multicolumn{3}{|c|}{$\begin{array}{l}\text { Values are } n(\%) \text { unless specified. } \\
\text { *Other includes jail/recovery/transition house/squats/street/no fixed } \\
\text { address. }\end{array}$} \\
\hline
\end{tabular}

analysed using Pearson's $\chi^{2}$ test, and the Wilcoxon rank-sum test was used for continuous variables. For this comparison, we identified 234 female sex workers, defined as those who were sexually active and reported selling sex in the six months before study enrolment. The condom use and sex partner information in table 3 was taken from the questionnaire administered at the most recent follow up visit (June to December 2000) and identified 163 women actively engaged in commercial sex work. Drug use and other behavioural variables referred to activities in the past six months.

\section{RESULTS}

\section{Demographics}

The demographic characteristics of the VIDUS cohort are shown in table 1. Male participants are older and have longer injection careers than female participants. The ethnic make-up of the cohort generally reflects the community, with a disproportionate number of female subjects among the Canadian aboriginal participants. The majority of the Hispanic population is male. The most common housing arrangements are single occupancy hotel rooms that are rented by the month. Seventy per cent of the participants receive government welfare payments for housing and other support. The prevalence of HIV-l is higher among women (35\% v 26\%) and the prevalence of hepatitis $\mathrm{C}$ is similar among women and men.

\section{Sexual activity and reported condom use}

Table 2 summarises the reported sexual activity collected from baseline questionnaires. During the six months before enrolment, $72 \%$ of men and $92 \%$ of women reported some sexual activity. The majority reported heterosexual partners, although same sex partners were not uncommon. Among male subjects, 39\% reported fewer than 20 lifetime sex partners, while $78 \%$ reported fewer than 100. In contrast, $26 \%$ of female subjects reported fewer than 20 lifetime partners and $43 \%$ reported less than 100 . The high proportion of women involved in the sex trade was reflected in the observation that $57 \%$ of women reported at least 100 lifetime partners.
Table 2 Sexual activity of the Vancouver injection drug users study (VIDUS) cohort stratified by sex

\begin{tabular}{llll}
\hline Sexual activity & $\begin{array}{l}\text { Male } \\
(n=932)\end{array}$ & $\begin{array}{l}\text { Female } \\
(n=505)\end{array}$ & $\begin{array}{l}p \\
\text { Value }\end{array}$ \\
\hline Age at first sex (mean (range)) (years) & $\begin{array}{l}14.7 \\
(11 \text { to } 24)\end{array}$ & $\begin{array}{l}14.9 \\
(9 \text { to } 22)\end{array}$ & 0.02 \\
& $669(72)$ & $464(92)$ & 0.001 \\
Any sexual activity (past 6 months) & & & \\
Of those having sex: & $583(87)$ & $385(83)$ & \\
opposite sex only & $49(7)$ & $16(4)$ & \\
same sex only & $37(6)$ & $63(13)$ & 0.001 \\
same and opposite sex & & & \\
Number of lifetime partners & $130(14)$ & $55(11)$ & \\
5 or less & $229(25)$ & $75(15)$ & \\
6-19 & $370(40)$ & $87(17)$ & \\
20-99 & $161(17)$ & $93(18)$ & \\
$100-499$ & $42(4)$ & $195(39)$ & 0.001 \\
500 or more & & & \\
\hline Values are $\mathrm{n}(\%)$ unless specified. & & & \\
\hline
\end{tabular}

Table 3 summarises the reported frequency of sexual activity, the type of sexual activity, and condom use, stratified by regular partners, casual partners, and paid partners. Of participants who reported any sexual activity in the past six months, 593 (56\%) reported having a regular sex partner of the opposite sex, defined as "someone you have had a sexual relationship with for more than three months." Women were more likely to report having a regular sex partner then men $(63 \% \vee 51 \%, p<0.001)$. Vaginal sex was reported by $99 \%$ of male and female participants. The reported frequency of vaginal intercourse was at least one to three times a week by $79 \%$ of men and $74 \%$ of women. Overall, $65 \%$ of participants never used condoms during vaginal intercourse with their regular partner. Seventy six per cent of participants had engaged in oral sex in the past six months. Condom use during oral sex with a regular partner was very uncommon. Anal sex with a regular partner was reported by $20 \%$ of participants but was practiced infrequently.

One or more casual sex partners of the opposite sex were reported by 471 ( $45 \%$ ) of participants. Although vaginal intercourse was reported by $95 \%$ of respondents, $63 \%$ reported this activity less than once a week. Condoms were "always" used during vaginal sex with casual partners by about half of the participants. Oral sex was reported by 53\% of this group but was also relatively infrequent. Condoms were generally not used during oral sex with casual partners. Ten per cent of male participants and only $5 \%$ of female participants reported anal sex with casual partners.

Nine per cent of men reported sex with other men in past six months. Oral sex was reported by $95 \%$ of this group, with receptive and insertive anal intercourse reported by $32 \%$. For oral sex, condoms were "always" used with paying partners by $60 \%$. Of the men who reported anal sex with paid contacts, $71 \%$ reported "always" using condoms. Of the 182 female participants who reported commercial sex work in the past six months, $163(90 \%)$ had paying heterosexual partners or "tricks". Vaginal sex was practiced by $90 \%$, with $92 \%$ reporting a frequency of at least one to three times a week. Condom use was relatively high, with $82 \%$ reporting that they "always" used a condom. Oral sex was reported by $99 \%$, with $94 \%$ having at least one to three contacts a day. Seventy five per cent reported that they "always" used a condom during oral sex. Anal sex was relatively uncommon and infrequent among female sex workers.

\section{Female sex workers}

Table 4 compares the baseline demographic and drug use characteristics of female sex workers with other women in the cohort. Female sex workers were less likely to have a 
Table 3 Reported sexual practices and condom use with regular, casual, and paying partners stratified by sex

\begin{tabular}{|c|c|c|c|c|c|c|c|}
\hline \multirow{2}{*}{\multicolumn{2}{|c|}{ Sexual practices }} & \multicolumn{2}{|c|}{ Regular partners } & \multicolumn{2}{|c|}{ Casual partners } & \multicolumn{2}{|c|}{ Paid partners } \\
\hline & & $\begin{array}{l}\text { Male } \\
(n=317)\end{array}$ & $\begin{array}{l}\text { Female } \\
(n=283)\end{array}$ & $\begin{array}{l}\text { Male } \\
(n=352)\end{array}$ & $\begin{array}{l}\text { Female } \\
(n=121)\end{array}$ & $\begin{array}{l}\text { Male } \\
(n=64)\end{array}$ & $\begin{array}{l}\text { Female } \\
(n=163)\end{array}$ \\
\hline Vaginal sex & & 315 (99) & 279 (99) & 334 (95) & 117 (97) & NA & $148(90)$ \\
\hline Frequency: & $\begin{array}{l}\text { Less than weekly } \\
1-3 \text { times a week } \\
\text { Once a day or more }\end{array}$ & $\begin{array}{l}66(21) \\
143(45) \\
106(34)\end{array}$ & $\begin{array}{l}74(26) \\
130(47) \\
75(27)\end{array}$ & $\begin{array}{l}213(64) \\
84(25) \\
33(10)\end{array}$ & $\begin{array}{l}83(71) \\
25(21) \\
9(8)\end{array}$ & $\begin{array}{l}\text { NA } \\
\text { NA } \\
\text { NA }\end{array}$ & $\begin{array}{l}10(6) \\
51(35) \\
87(59)\end{array}$ \\
\hline Condoms: & $\begin{array}{l}\text { Always } \\
\text { Sometimes } \\
\text { Never }\end{array}$ & $\begin{array}{l}69(22) \\
59(19) \\
187(59)\end{array}$ & $\begin{array}{l}48(17) \\
26(9) \\
205(74)\end{array}$ & $\begin{array}{l}178(53) \\
73(22) \\
83(25)\end{array}$ & $\begin{array}{l}58(50) \\
23(20) \\
36(31)\end{array}$ & $\begin{array}{l}\text { NA } \\
\text { NA } \\
\text { NA }\end{array}$ & $\begin{array}{l}121(82) \\
24(16) \\
3(2)\end{array}$ \\
\hline Oral sex on & partner & 226 (71) & $230(81)$ & 172 (49) & 79 (65) & 61 (95) & 161 (99) \\
\hline Frequency: & $\begin{array}{l}\text { Less than weekly } \\
1-3 \text { times a week } \\
\text { Once a day or more }\end{array}$ & $\begin{array}{l}87(39) \\
98(43) \\
41(18)\end{array}$ & $\begin{array}{l}89(39) \\
108(47) \\
33(14)\end{array}$ & $\begin{array}{l}125(73) \\
31(18) \\
16(9)\end{array}$ & $\begin{array}{l}57(73) \\
17(22) \\
5(6)\end{array}$ & $\begin{array}{l}16(27) \\
11(19) \\
32(54)\end{array}$ & $\begin{array}{l}10(6) \\
23(14) \\
128(80)\end{array}$ \\
\hline Condoms: & $\begin{array}{l}\text { Always } \\
\text { Sometimes } \\
\text { Never }\end{array}$ & $\begin{array}{l}7(3) \\
10(4) \\
209(93)\end{array}$ & $\begin{array}{l}38(16) \\
15(7) \\
177(77)\end{array}$ & $\begin{array}{l}20(12) \\
8(5) \\
144(83)\end{array}$ & $\begin{array}{l}26(33) \\
10(13) \\
43(54)\end{array}$ & $\begin{array}{l}37(60) \\
15(25) \\
9(15)\end{array}$ & $\begin{array}{l}121(75) \\
36(21) \\
6(4)\end{array}$ \\
\hline Anal sex & & $68(21)$ & $51(18)$ & 35 (10) & $6(5)$ & 21 (32) & 21 (13) \\
\hline Frequency: & $\begin{array}{l}\text { Less than weekly } \\
1-3 \text { times a week } \\
\text { Once a day or more }\end{array}$ & $\begin{array}{l}46(68) \\
17(26) \\
5(7)\end{array}$ & $\begin{array}{l}42(83) \\
7(14) \\
2(4)\end{array}$ & $\begin{array}{l}23(65) \\
11(31) \\
1(3)\end{array}$ & $\begin{array}{l}6(100) \\
0(0) \\
0(0)\end{array}$ & $\begin{array}{l}10(48) \\
9(43) \\
2(9)\end{array}$ & $\begin{array}{l}18(86) \\
3(14) \\
0(0)\end{array}$ \\
\hline Condoms: & $\begin{array}{l}\text { Always } \\
\text { Sometimes } \\
\text { Never }\end{array}$ & $\begin{array}{l}15(22) \\
10(15) \\
43(63)\end{array}$ & $\begin{array}{l}9(18) \\
1(2) \\
41(80)\end{array}$ & $\begin{array}{l}14(40) \\
4(11) \\
17(49)\end{array}$ & $\begin{array}{l}3(50) \\
0(0) \\
3(50)\end{array}$ & $\begin{array}{l}15(71) \\
4(19) \\
2(10)\end{array}$ & $\begin{array}{l}17(81) \\
1(9) \\
2(10)\end{array}$ \\
\hline
\end{tabular}

regular sex partner. There was no statistically significant ethnic difference among women involved in sex work, although aboriginal women tended to be less involved. Female sex workers were more likely to live in the DTES, to have unstable housing arrangements, and to report incarceration in the previous six months. Regular heroin use was marginally higher among female sex workers, although frequent injection cocaine and crack cocaine use was much more com- mon in this group. The HIV prevalence was higher among women who sold sex. At baseline, HIV prevalence was 32\% among female sex workers and $21 \%$ among non-sex-workers. HIV seroconversion during follow up was documented in $10 \%$ of active female sex workers and $7 \%$ of the other female participants. The reported occurrence of an STD was relatively uncommon overall, although marginally higher among female sex workers.

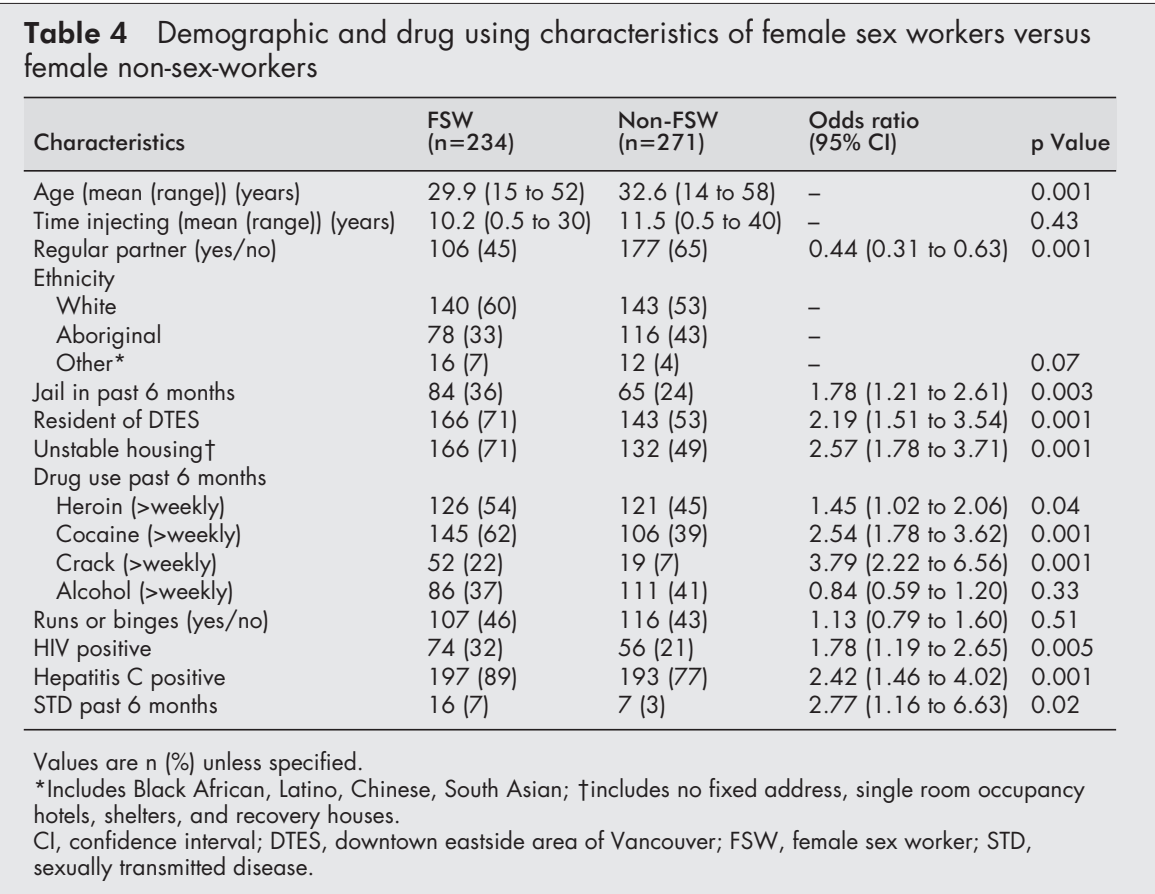


Table 5 History of reported lifetime sexually transmitted diseases (non-ulcerative and ulcerative), stratified by sex

\begin{tabular}{llll}
\hline Characteristic & $\begin{array}{l}\text { Male } \\
(\mathbf{n}=932)\end{array}$ & $\begin{array}{l}\text { Female } \\
(\mathbf{n}=505)\end{array}$ & $\mathrm{p}$ Value \\
\hline Any STD ever & $395(42)$ & $290(57)$ & 0.001 \\
$\quad$ gonorrhea/chlamydia ever & $282(30)$ & $215(43)$ & 0.001 \\
syphilis/herpes ever & $128(14)$ & $96(19)$ & 0.008 \\
& $11(1)$ & $23(5)$ & 0.001 \\
Any STD past 6 months & $11)$ & $6(1)$ & 0.05 \\
$\quad$ gonorrhea/chlamydia ever & $3(<1)$ & $13(3)$ & 0.001 \\
$\quad$ syphilis/herpes ever & $5(<1)$ & & \\
\hline & & & \\
Values are $\mathrm{n}(\%)$. & & \\
STD, sexually transmitted disease. &
\end{tabular}

\section{STD history}

STD history among male and female participants is shown in table 5. Compared with the men, the women in the cohort are more likely to have had an STD in the past. This association is consistent for both non-ulcerative (gonorrhoea and chlamydia) and ulcerative infections (syphilis and herpes). For the 685 participants reporting a previous STD, the rate of HIV was marginally higher $(53 \% \vee 46 \%$; $\mathrm{p}=0.05)$. This association was similar when stratified by sex.

\section{Sexual networks}

Figure $\mathrm{l}$ is a compartment model from the DTES with female sex workers as the core group. Although many of these women also use injection drugs, there is a sizeable minority who do not. Endemic rates of STDs are sustained among the female sex workers by sexual activity with males who reside in the DTES. These men can be classified into four general categories. Group 1 consists of regular male sex partners who use injection drugs and also reside in the DTES. The money generated by their female partner's sex work also helps to support their drug use. Group 2 consists of regular male sex partners who do not use injection drugs themselves. Some of these arrangements are based on the organised recruitment of women through drugs and intimidation. Group 3 consists of resident males who purchase sex and do not inject drugs. These are mainly older men who are long term residents of the community and are marginalised because of various physical and mental ailments. Group 4 consists of resident males who are injection drug users and purchase sex. As most men in the area do not have regular sex partners, much of their sexual activity occurs with paid partners. This may also include sexfor-drugs arrangements.

The bridging to populations outside the DTES occurs primarily through men who visit the DTES specifically for sex. The sex may occur within the hotel system in the DTES or by driving to locations outside the area. These men are usually non-injection drug users and have both casual and regular sex partners residing outside of the DTES. A second important bridging population is foreign visitors to the area, either tourists or ship workers stopping at the Vancouver port. This type of sexual contact has far reaching implications for the transmission of STDs/HIV to other cities. It is also a potential route for STD pathogens to be introduced into the community.

\section{DISCUSSION}

The complex interaction between illicit drug use and commercial sex work presents major challenges for STD prevention and policy. ${ }^{34}$ The DTES of Vancouver provides a graphic example of how an explosive outbreak of HIV infection occurred among a population of injection drug users despite a range of public health interventions including a legal needle exchange, methadone maintenance treatment, and free health care. ${ }^{15}$ The transmission of other STDs and the contribution of sexual transmission to the HIV outbreak have received less attention. A recent outbreak of syphilis in the province of British Columbia, however, traced the epicentre of transmission to the DTES, leading to a syphilis mass treatment campaign in the neighbourhood.

The transmissibility of HIV through blood to blood contact, as occurs among injection drug users, is thought to be severalfold higher than through sexual transmission. ${ }^{18}$ Therefore the actual proportion of HIV resulting from sexual transmission in this population is difficult to determine. However, the concentration of female sex workers, the large numbers of sex partners, the complex networks that have evolved, and the relatively low rates of condom use create an environment where sexual transmission of HIV does occur. ${ }^{19}{ }^{20}$ In addition, sexual relationships and intimacy are closely linked to drug using patterns and needle sharing. ${ }^{2122}$ Rothenberg et al propose that the formation of social networks may act as a barrier or a facilitator for disease transmission and that the context for risk behaviours influences transmission dynamics. ${ }^{14}$ The geographical concentration of injection drug users in the DTES lends itself to these influences, and understanding these dynamics has implications for prevention strategies.

The relatively low uptake of condoms and the large number of sex partners documented in this cohort study are consistent with other injection drug user populations.$^{43}$ Female injection drug users who also sell sex continue to put themselves at high risk, knowing they are in an environment with extremely high rates of HIV and other STDs. Drug addiction propels many women into sex work in order to provide the money needed to maintain their drug habits. As demonstrated in this cohort, women injection drug users who sold sex were more likely to be resident in the DTES and to have unstable housing situations, and were less likely to have regular sex partners. The intensity of drug use was also significantly higher in this group, compared with women who did not sell sex. Drugs impair judgement, making attempts to use condoms consistently or avoid high risk sexual behaviours difficult, even for the most motivated and well informed. As with other studies in drug using populations, we found that injection cocaine and crack cocaine were commonest among female sex workers. ${ }^{24}$

Several interventions designed to reduce sexual risk behaviours among injection drug users have been developed. Outreach and community based programmes that promote safer sexual practices can be successful in some situations. ${ }^{25}$ Further, it has been shown that those in drug treatment programmes are less likely to engage in high risk sexual activities than those out of treatment ${ }^{26}$ Methadone maintenance treatment participants have also been shown to have fewer sexual

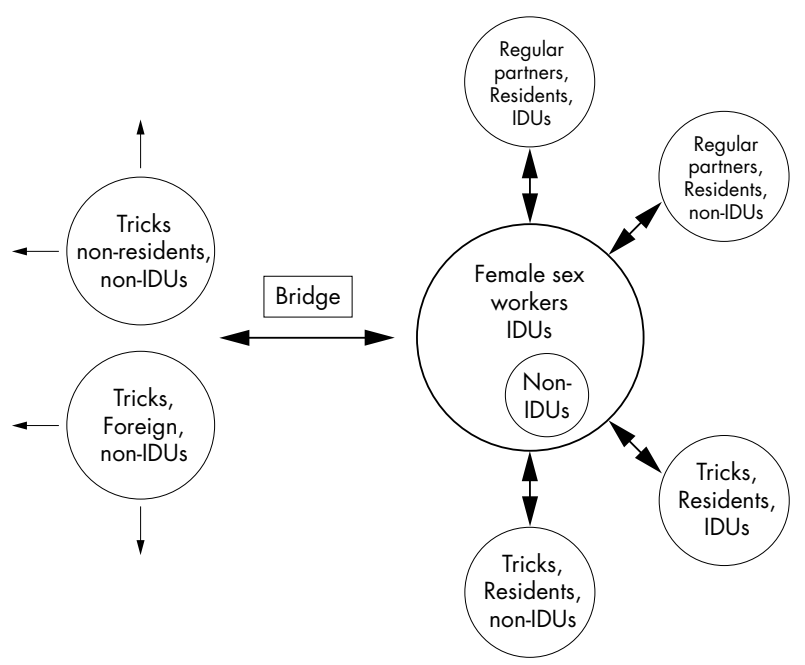

Figure 1 Compartment model for female sex workers in downtown eastside (DTES) of Vancouver. 
partners and in some cases are able to disengage from commercial sex work. ${ }^{27}$ Certainly these initiatives need to be expanded and applied to other communities.

In the dynamic topology of STD epidemics described by Wasserheit and $\mathrm{Aral}^{28}$ the population in the DTES has the characteristics consistent with phase IV epidemics. This includes a geographically concentrated subpopulation with high rates of partner change and little contact with the health care system. Further, external factors such as poverty, low levels of education, and illicit drug use serve to sustain the epidemic in this community. The VIDUS cohort illustrates how these factors can converge to push individuals to the margins of society where interventions are more difficult to initiate.

Strategies that primarily target "spread networks" have been a priority in this community. In a phase IV epidemic environment this would include targeted health promotion activities. In the DTES there has been a wide range of targeted health promotion initiatives including safe sex posters and pamphlets distributed by health clinics and community groups, peer risk reduction counselling delivered through support groups for sex workers and injection drug users, and an active street nurse programme that delivers information directly to individuals who engage in high risk behaviours. The introduction of partner notification is particularly difficult in this community. There is a general reluctance to cooperate with health officials in divulging names and addresses, as such people are perceived to be associated with the criminal justice system. Many of the highest risk individuals have previous drug related convictions and fear arrest and conviction on illicit drug charges.

As the epidemic progresses through phases, the subpopulations become characterised by progressively higher rates of partner change, less effective contact with the health care system, and lower educational and social status. ${ }^{28}$ This is very characteristic of injection drug user populations, when drug users spend increasing resources on illegal drugs and are driven further away from social support systems. The large proportion of individuals who receive a criminal conviction for drug related offences (more than $70 \%$ in our cohort) may also limit the future potential for housing and employment.

Intervention research is imperative to help better define optimal approaches to STD control in this population. This is important not only to reduce the sexual transmission of HIV within the community but also to prevent transmission of infections to the bridging populations. As illustrated in fig l, the central location of this community allows contacts with a range of non-residents. The open illicit drug markets, as well as the commercial sex trade, draw people to this neighbourhood. As described by Wasserheit and Aral, research on bridge populations is crucial as this group serves to maintain transmission to other populations.

This study has some limitations inherent to prospective cohort studies. Although follow up exceeds $80 \%$, there is a loss to follow up that may introduce bias. It is probable that the higher risk participants are less likely to return, and therefore high risk behaviours are underestimated. Further, we rely on participants identifying themselves to the study and this may attract higher risk individuals and limit the extent to which the results can be generalised to the injection community as a whole. Self reporting drug use and sexual behaviours may be prone to socially desirable responses and poor recall. However, there is some evidence that the validity of self reported drug use behaviours is not seriously compromised in this population..$^{29}$ In any case this would be likely to lead to an overreporting of condom use and an underreporting of high risk sexual activities, making the study observations even more compelling. Finally, we did not routinely perform diagnostic STD testing and could not determine with certainty the pathogen specific phases of the epidemic.

The transmission of STDs in drug using communities requires urgent study. It is clear that female drug users who also sell sex are a population in need of intensive STD prevention interventions. While providing condoms, free diagnostic testing, and antimicrobial treatment are important components of prevention, they have not been sufficient. Existing programmes should be strengthened, but innovative approaches to STD surveillance, diagnosis, and prevention are needed. One approach would be to form closer links between STD prevention and existing harm reduction initiatives. Reducing STD transmission among injection drug users has far reaching implications for STD control in general and remains a major public health challenge.

\section{ACKNOWLEDGEMENT}

Tha authors with to thank participants and staff of the VIDUS project.

Authors' affiliations

M W Tyndall, P Spittal, K Li, M V O'Shaughnessy, M T Schechter, British Columbia Centre for Excellence in HIV/AIDS, St Paul's Hospital, Vancouver, Canada

D Patrick, Department of Health Care and Epidemiology, University of British Columbia, Vancouver, Canada

\section{REFERENCES}

1 Friedman SR, Jose B, Deren S, et al. Risk factors for human immunodeficiency virus seroconversion among out-of-treatment drug injectors in high and low seroprevalence cities. The National AIDS Research Consortium. Am J Epidemiol 1995;142:864-74.

2 Solomon L, Astemborski J, Warren D, et al. Differences in risk factors for human immunodeficiency virus type 1 seroconversion among male and female intravenous drug users. Am J Epidemiol 1993;137:892-8.

$3 \mathrm{Kral} \mathrm{AH}$, Lorvick J, Edlin BR. Sex- and drug-related risk among populations of younger and older injection drug users in adjacent neighborhoods in San Francisco. J Acquir Immune Defic Syndr 2000;24:162-7.

4 Astemborski J, Vlahov D, Warren D, et al. The trading of sex for drugs or money and HIV seropositivity among female intravenous drug users. Am J Public Health 1994;84:382-7.

5 Stevens SJ, Estrada AL, Estrada BD. HIV sex and drug risk behavior and behavior change in a national sample of injection drug and crack cocaine using women. Women Health 1998;27:25-48.

6 Molitor F, Ruiz JD, Flynn N, et al. Methamphetamine use and sexual and injection risk behaviors among out-of-treatment injection drug users. $\mathrm{Am} J$ Drug Alcohol Abuse 1999:25:475-93.

7 Elifson KW, Boles J, Darrow WW, et al. HIV seroprevalence and risk factors among clients of female and male prostitutes. J Acquir Immune Defic Syndr Hum Retrovirol 1999;20:195-200.

8 Paone D, Caloir S, Shi Q, et al. Sex, drugs, and syringe exchange in New York City: women's experiences. J Am Med Womens Assoc 1995:50:109-14.

9 Edlin BR, Irwin KL, Faruque S, et al. Intersecting epidemics - crack cocaine use and HIV infection among inner-city young adults. Multicenter Crack Cocaine and HIV Infection Study Team. N Engl J Med 1994;331:1422-7.

10 Hudgins R, McCusker J, Stoddard A. Cocaine use and risky injection and sexual behaviors. Drug Alcohol Depend 1995;37:7-14.

11 Rhodes T, Stimson GV, Crofts N, et al. Drug injecting, rapid HIV spread and the "risk environment": implications for assessment and response. AIDS 1999;13(suppl A):S259-69.

12 Moss AR, Vranizan K, Gorter R, et al. HIV seroconversion in intravenous drug users in San Francisco, 1985-1990. AIDS 1994;8:223-31.

13 Rothenberg RB, Potterat JJ, Woodhouse DE, et al. Social network dynamics and HIV transmission. AIDS 1998;12:1529-36.

14 Rothenberg RB, Potterat JJ, Woodhouse DE. Personal risk taking and the spread of disease: beyond core groups. J Infect Dis 1996;174/suppl 2):S144-9.

15 Schechter MT, Strathdee SA, Cornelisse PG, et al. Do needle exchange programmes increase the spread of HIV among injection drug users? An investigation of the Vancouver outbreak. AIDS 1999:13:F45-51.

16 Strathdee SA, Patrick DM, Currie SL, et al. Needle exchange is not enough: lessons from the Vancouver injecting drug use study. AIDS 1997; 11:F59-65

17 Office of the Chief Coroner. Illicit drug statistics for British Columbia. Vancouver: Office of the Chief Coroner, British Columbia Ministry of the Attorney General, 1999

18 Royce RA, Sena A, Cates W, et al. Sexual transmission of HIV. N Engl J Med 1997;336:1072-8

19 Rhodes T, Stimson GV, Quirk A. Sex, drugs, intervention, and research: from the individual to the social. Subst Use Misuse 1996:31:375-407.

$20 \mathrm{Kral} \mathrm{AH}$, Bluthenthal RN, Lorvick J, et al. Sexual transmission of HIV-1 among injection drug users in San Francisco, USA: risk-factor analysis. Lancet 2001;357:1397-401.

21 Paone D, Des Jarlais DC, Caloir S, et al. Continued risky injection subsequent to syringe exchange use among injection drug users in New York City. AIDS Educ Prev 1997;9:505-10. 
22 Gossop MPG, Powis B, Williamson S, et al. Continuing drug risk behaviour: shared use of injecting paraphernalia among London heroin injectors. AIDS Care 1997;9:651-60.

23 King VL, Brooner RK, Bigelow GE, et al. Condom use rates for specific sexual behaviors among opioid abusers entering treatment. Drug Alcohol Depend 1994:35:231-8.

24 DeHovitz JA, Kelly P, Feldman J, et al. Sexually transmitted diseases, sexual behavior, and cocaine use in inner-city women. Am J Epidemiol 1994; 140:1125-34.

25 Rhodes T, Donoghoe M, Hunter G, et al. Sexual behaviour of drug injectors in London: implications for HIV transmission and HIV prevention. Addiction 1994;89:1085-96.
26 Longshore D, Hsieh SC, Anglin MD. Reducing HIV risk behavior among injection drug users: effect of methadone maintenance treatment on number of sex partners. Int J Addict 1994;29:741-57.

27 Watkins KE, Metzger D, Woody G, et al. High-risk sexual behaviors of intravenous drug users in- and out-of-treatment: implications for the spread of HIV infection. Am J Drug Alcohol Abuse 1992;18:389-98.

28 Wasserheit JN, Aral SO. The dynamic topology of sexually transmitted disease epidemics: implications for prevention strategies. J Infect Dis 1996;174(suppl 2):S201-13.

29 Weatherby N, Needle R, Cesari H, et al. Validity of self-reported drug use among injection drug users recruited through street outreach. Eval Prog Plan 1994; 17:347-55.

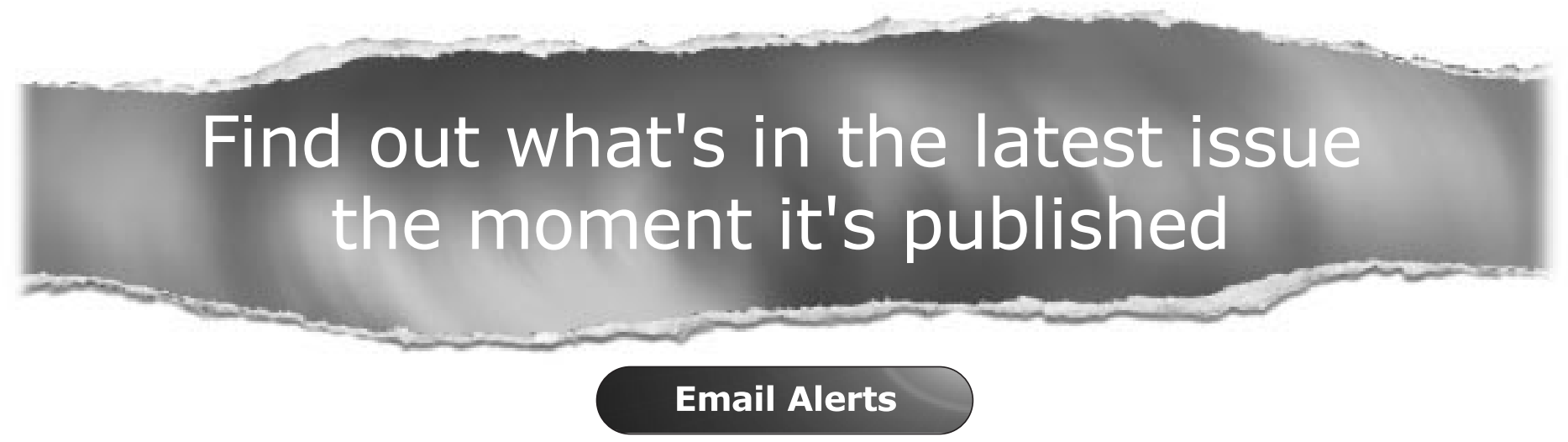

Sign up to receive the table of contents by email every month. You can select from three alerts: Table of Contents (full), TOC Awareness (notice only); Sexually Transmitted Infections related announcements.

www.sextransinf.com 